\title{
DEVELOPING HOTS-BASED GAME ON SCIENCE LEARNING FOR JUNIOR HIGH SCHOOL STUDENTS
}

\author{
Arum Adita, S.Pd.,M.Pd \\ Universitas Muhammadiyah Purwokerto \\ Purwokerto, Indonesia
}

\author{
Listika Yusi R, S.Pd.,M.Pd \\ Universitas Muhammadiyah Purwokerto \\ Purwokerto, Indonesia
}

\begin{abstract}
It is suggested that school apply instructional games in science learning since it will make learners motivated to learn especially the lesson with difficult material. The purpose of this study is to find out the aspects to prepare HOTS-based games for science learning and find out the feasibility of HOTS-based games in junior high school according to teachers and students. ADDIE (Analysis, Design, Development \& Production, Implementation, Evaluation) model was applied in this research and development. In the early development stage, the game draft was validated by media and material experts. In the implementation phase, a limited trial was conducted in Grade VI of SMP N 5 Purwokerto. The data obtained was then analyzed descriptively to process the quality data of the game. Based on students' and teachers' questionnaire, it is proven that the quality of the product is in very good and good category.
\end{abstract}

\section{Keywords: Development, IPA games, HOTS}

\section{Introduction}

The integration of information and communication technology (ICT) in education is not a new thing anymore. In Indonesia, many teachers have already applied multimedia in science learning but many others have not applied it yet (Tiawa, Mislan, Wibowo, \&Sumintono, 2012). The ICT use in learning is mostly by software to give presentations or other audiovisual programs, but less by instructional games. Game is a media composed of audio visual elements with fun characteristics, feedback, rewards and challenges. Educational games are easy to find and download by students, nevertheless not many games are based on instructional or curriculum objectives in school. It commonly occurred because the preparation activities of instructional game are considered to waste times and energy, likely in the game design of science learning (Li \& Tsai, 2013).

Nowadays, most students are labeled as digital native who depends on technology every day. The use of digital media in learning is important since most children aged 8-18 like spending more time by playing video games than reading books (J.R., Foehr, \& Roberts, 2010). Access to information / material is not always gained from school, it could be wherever or whenever, it always becomes the main attraction for learners. Therefore, it needs prepared games especially to help learners in understanding the material. Learning using games can make learners motivated since it transforms boring into interactive learning (Johnson et al., 2012). Media for students of junior high school
(SMP) should be developed well, interestingly, and imaginatively, in particular to make good comprehension of difficult material or related to constraints of laboratory equipment such as in science subjects.

The delivery of interesting material could make learning more meaningful. According Ausubel (Carin, 1997), meaningful learning is a new learning associated with previous information or experience. Video games are able to stimulate the formation of mental structures from natural phenomena compared to traditional learning. The formation of mental / cognitive structures gained directly from the learners' experience could make the cognitive structures last long (Corredor, Gaydos, \& Squire, 2014).

Game development is supposed to be meaningful learning rather than a collection of questions (Barko\&D.Sadler, 2012). Meaningful learning means that the game is able to involve the ability of high-level thinking or known as High Order Thinking Skill (HOTS). According to (Sutrisno, 2011) HOTS can be developed through ICT-based learning. In addition to developing HOTS, ICT can also be used to develop $21^{\text {st }}$ century capabilities such as innovation, creativity and ICT literacy. ICT literacy is the ability to use digital technology either to access, manage or create information for communication purposes (Sutrisno, 2011). Similar to real laboratory- based learning, ICT-based learning also improve the skill of science process (Mulyani, Liliasari, Wiji, Hana, \& E.Nursa'adah, 2016). Based on the advantages of ICT in developing HOTS and the lack of development of instructional games, it is necessary to develop instructional games based on 
HOTS on science subjects to support 21st century skills. This research aims to:

1. find out the aspects to be considered in the preparation of HOTS-based games for science learning.

2. find out the feasibility of HOTS-based games in junior high school according to teacher and students as users.

\section{Research method}

\section{A. Game Formulation Procedures}

This research and development applied a descriptive procedural model outlining the steps followed to produce the product (Sugiyono, 2008). ADDIE (Analisys, Design, Development and Production, Implementation, Evaluation) is used as the stages of this research (DewiPadmo, 2004).

\section{Analysis}

At this stage, the level of depth of competence required by the curriculum was measured. It is also a must that the students' experience and learning styles are able to meet the needs of all users of educational games. At this stage, existing competencies in the curriculum is explored to be the goal and indicator of learning.

\section{Designing}

Based on the above analysis, the framework and design of educational game was created. In this stage, it started from determining the material framework to be displayed.

\section{Development and production}

This activity is also called reviewedit. Editing is done by lecturers of material and media experts

\section{Implementation}

A trial to find out the quality of HOTS-based games was conducted in this stage.

\section{Evaluation}

This stage included product evaluations that have been implemented in schools.

\section{B. Subject and Object Research}

The subject of this research is the seventh grade students of junior high school in Purwokerto. The object of research is the quality of IPA games based on HOTS.

\section{Research instruments}

The research instruments used were as follow:

a. Questionnaire of game quality by material and media experts

b. Questionnaire of game quality according to teacher and student

\section{Data Collection Techniques}

The regulation of data collection technique are as follow:

c. Find out the preliminary information about aspects of game development through questionnaires.

d. Test the feasibility of games created with the validation by lecturers of material and media experts through questionnaires

e. Find out the responses of students and teachers to the quality of the game through a questionnaire.

\section{E. Instrument Validation}

Validity is a measure of the validity instrument. The validity of the instrument shows how far the instrument can measure what to measure. The game quality assessment instrument in the form of a questionnaire is validated using construction validation by the opinion of experts (judgment experts). SPSS was used as validity and reliability test instruments. The instrument used was reliable with Cronbach's alpha 0.831 .

\section{F. Data analysis techniques}

Descriptive technique as the data analysis technique is used to process data quality evaluation results based on games questionnaire with the following steps:

a. Converting a score in qualitative form to a quantitative value with a Likert scale. Rule weighting scores on each item of statement is done under the following conditions:

Table 1. Scoring Weight Rules

\begin{tabular}{|l|l|}
\hline Ranking Score & Score \\
\hline Strongly agree & 4 \\
\hline Agree & 3 \\
\hline Disagree & 2 \\
\hline Less agree & 1 \\
\hline From the recapitulation result, average \\
score is calculated from each component \\
of assessment with formula: \\
X= $\frac{\sum x}{n}$ \\
Description: \\
X: average score \\
Ex: total score of each component of the \\
assessment \\
$\mathrm{N}:$ number of respondents / validators
\end{tabular}


b. Determining an assessment based on the scoring criteria as it appears on table 2

Table 2. Assessment criteria

\begin{tabular}{|l|l|}
\hline Value Interval & Criteria \\
\hline $\mathrm{Mi}+1,5 \mathrm{Sbi} \leq \mathrm{X} \leq \mathrm{Mi}+3,0 \mathrm{Sbi}$ & $\begin{array}{l}\text { Very } \\
\text { good }\end{array}$ \\
\hline $\mathrm{Mi}+0 \mathrm{Sbi} \leq \mathrm{X}<\mathrm{Mi}+1,5 \mathrm{Sbi}$ & Good \\
\hline $\mathrm{Mi}-1,5 \mathrm{Sbi} \leq \mathrm{X}<\mathrm{Mi}+0 \mathrm{Sbi}$ & Less \\
\hline $\mathrm{Mi}-3 \mathrm{Sbi} \leq \mathrm{X}<\mathrm{Mi}-1,5 \mathrm{Sbi}$ & $\begin{array}{l}\text { Very } \\
\text { poor }\end{array}$ \\
\hline
\end{tabular}

Description:

$\mathrm{X}$ : average of actual score

Mi: ideal mean

Sbi: ideal standard deviation

Mi: $\frac{1}{2}$ (ideal highest score + ideal lowest score)

Sbi: $\frac{1}{6}$ (ideal highest score - ideal lowest score)

\section{Results and Discussion}

\section{A. Research Result}

The result of this research and development is the product of educational game "let's help". ADDIE (Analisys, Design, Development and Production, Implementation, Evaluation). model was used as the stages model in this research.

1. Analysis

a. Competence Analysis

Standard Competence

Analysis (KI) and Basic Competency (KD) refers to the Curriculum 2013 compiled by the National Standardization Agency for Education (BSNP), namely KI and KD for class VII third semester of SMP.

Table 3. Competencies in the 2013 curriculum used

\begin{tabular}{|l|l|}
\hline Standard & $\begin{array}{l}\text { Understand (factual, } \\
\text { Competence } \\
\text { on curiosity about science, } \\
\text { technology, art, culture related } \\
\text { eye-catching phenomena and } \\
\text { events }\end{array}$ \\
\hline Basic & $\begin{array}{l}\text { Understand the concept of } \\
\text { measurement of the various } \\
\text { magnitudes that exist in self, } \\
\text { living things and the } \\
\text { surrounding physical } \\
\text { environment as part of the } \\
\text { observation, as well as the } \\
\text { importance of formulation of } \\
\text { standardized units (raw) in } \\
\text { measurement }\end{array}$ \\
\hline
\end{tabular}

b. Learner Character Analysis

Learners who become potential users of the game were students of SMP class VII. Learners have been able to think abstract (formal operational).

c. Instructional Analysis

The purpose of this analysis is to establish the basics needed for game development based on the 2013 curriculum on science learning in schools.

Table 4. Results of instructional analysis and indicators.

\begin{tabular}{|c|c|}
\hline Learning Objectives & Indicators \\
\hline $\begin{array}{l}\text { Understand the concept } \\
\text { of measurement of the } \\
\text { various magnitudes that } \\
\text { exist in self, living } \\
\text { creatures and the } \\
\text { surrounding physical } \\
\text { environment as part of } \\
\text { the observation, as well } \\
\text { as the importance of } \\
\text { standardized formulation } \\
\text { in the measurement }\end{array}$ & $\begin{array}{l}\text { 1. Solving problems } \\
\text { related to } \\
\text { measurement } \\
\text { problems } \\
\text { 2. Distinguishing } \\
\text { the concept of } \\
\text { magnitude and } \\
\text { unit } \\
\text { 3. Distinguishing } \\
\text { between } \\
\text { standardized and } \\
\text { non-standard } \\
\text { units } \\
\text { 4. Performing a } \\
\text { series of } \\
\text { measuring } \\
\text { processes } \\
\text { correctly through } \\
\text { the procedures in } \\
\text { the game } \\
\text { 5. Being able to } \\
\text { convert units }\end{array}$ \\
\hline
\end{tabular}

2. Designing

This stage involves making game design. The game is composed using a unity program with $\mathrm{C} \#$ programming language.

3. Development and Production

Stages of educational game preparation include asset creation, asset pooling and sound settings. The results of the development stage can be seen in the pictures below:

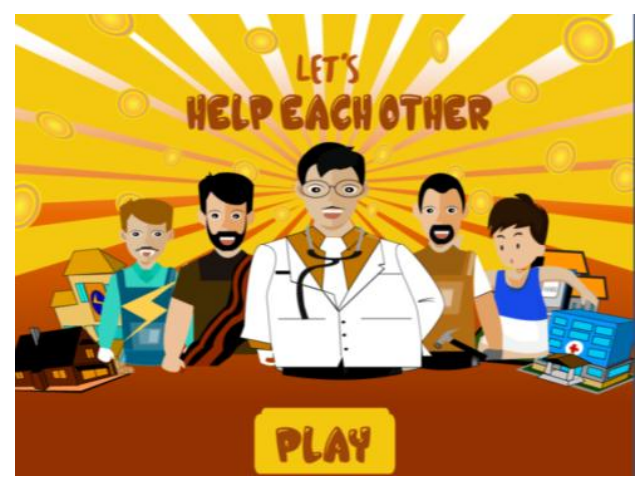

Figure 1: Play Display 


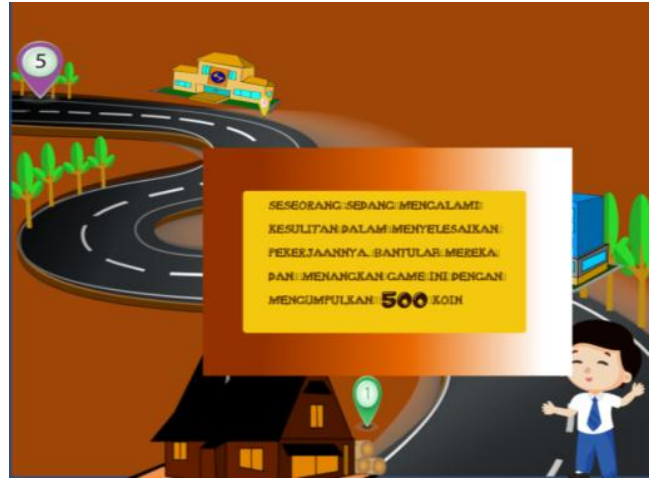

Figure 2 : Menu Display

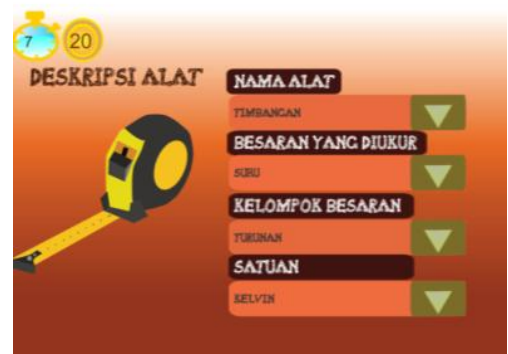

Figure 3. Game contents Display

Editing results by lecturers of media specialists and material experts:

1. Game instructions needs to be clarified

2. Game time needs to be reset in terms of its too fast game duration

3. Quit / close button needs to be added

At this stage, the game was improved based on suggestions from material and the media experts.

\section{Implementation}

At this stage, the tryout of the game is limited in one junior in Purwokerto namely SMP N 5 Purwokerto. Game quality test results can be seen in table 5 and 6 .

Table 5. Results of Game Quality based on Student Assessment

\begin{tabular}{|l|l|l|l|l|}
\hline No & $\begin{array}{l}\text { Assessment } \\
\text { Components }\end{array}$ & $\begin{array}{l}\text { Average } \\
\text { Score }\end{array}$ & Interval & Criteria \\
\hline 1 & Material coverage & 6,8125 & $6,5 \leq x \leq 8$ & $\begin{array}{l}\text { Very } \\
\text { Good }\end{array}$ \\
\hline 2 & $\begin{array}{l}\text { Encouraging } \\
\text { HOTS }\end{array}$ & 13,65625 & $13 \leq x<16$ & $\begin{array}{l}\text { Very } \\
\text { Good }\end{array}$ \\
\hline 3 & $\begin{array}{l}\text { Artistic and } \\
\text { aesthetic }\end{array}$ & 17,344 & $16,5 \leq x \leq 20$ & $\begin{array}{l}\text { Very } \\
\text { Good }\end{array}$ \\
\hline 4 & Overall function & 23,3844 & $22,75 \leq x \leq 28$ & $\begin{array}{l}\text { Very } \\
\text { Good }\end{array}$ \\
\hline 5 & Ease of Navigation & 16,375 & $22,75 \leq x \leq 28$ & $\begin{array}{l}\text { Very } \\
\text { Good }\end{array}$ \\
\hline
\end{tabular}

Table 6. Results of Game Quality based on teacher assessment

\begin{tabular}{|l|l|l|l|l|}
\hline No & $\begin{array}{l}\text { Assessment } \\
\text { Components }\end{array}$ & $\begin{array}{l}\text { Average } \\
\text { Score }\end{array}$ & Interval & Criteria \\
\hline 1 & Material coverage & 32 & $\begin{array}{l}26 \leq x \leq \\
32\end{array}$ & Very good \\
\hline 2 & $\begin{array}{l}\text { Encouraging } \\
\text { HOTS }\end{array}$ & 9 & $\begin{array}{l}7,5 \leq x< \\
9,75\end{array}$ & Good \\
\hline 3 & Artistic and & 18 & $\begin{array}{l}17,5 \leq x \\
<22,75\end{array}$ & Good \\
\hline 4 & Overall function & 10 & $\begin{array}{l}10 \leq x< \\
13\end{array}$ & Good \\
\hline 5 & Ease of Navigation & 15 & $\begin{array}{l}15 \leq x< \\
19,5\end{array}$ & Good \\
\hline
\end{tabular}

\section{Evaluation}

Based on the results of the tryout, the game is categorized in the range of good- very good product according to teachers and learners. Some things to note are technical issues related to file size and navigation buttons.

\section{B. Discussion}

As seen in the results of research, the stage in the making of games starts from instructional and learners analysis. The next step is designing, composing, testing and evaluating. Artistic, navigation and content are the aspects should be considered in making the games.

Based on the results of the tryout shown in table 6 and 7, the quality of the game is very good according to the teachers and students. The good quality of the product can be seen from several aspects such as material coverage, artistic and esthetic feature and ease of navigation. These results indicate that the media / games composed is one of the innovations that allow teachers to provide materials and facilitate student in learning. Yazdi and Zandkarimi (2013) explain that learning by using audio visual can motivate and improve learning. Barak, Ashkar and Dori (2011) also reveal that the use of multimedia shows a positive correlation between thinking ability and motivation. Motivation in this study is shown by good participation, interest, repetitive play, seriousness in every activity and as long as learning does not go far from learning topic. Some positive comments about the game are also revealed by most students. They claim that the game is very amusing to play. Moreover, more questions need to be added to practice. The teachers also mentions that some things related to overall functions and navigation need to be fixed.

This game is based on the ability of HOTS (high order thinking skills) which is closely related to an effort to improve students' thinking ability. This ability includes the ability to analyze, evaluate and create. Some scenes are made for high-level thinking such as problemsolving activities related to measurement 
problems and distinguishing between standard and non-standard units. This new game is created based on the ability to analyze. Problems are presented with several job settings including carpenters, doctors, merchants, electricians and runners. The first question is presented to explore students' ability to solve problems. For example, a fever student is displayed in the second scene, then the students are asked to choose a suitable measuring instrument. When students choose, students must have distinguished measuring tools relevant to the problem. The ability to differentiate involves the process of sifting through the relevant or important parts of a structure. This distinguishing ability is included in high-level thinking on analyzing (Anderson, 2010). Beside distinguishing, the other indicators in the ability to analyze is the ability to organize. It can be shown in the scene about the tool description. These activities involve the ability to organize that is building systematic and coherent relationships among pieces of information (Anderson, 2010).

Thus, learning by using educational game must be perfected. Excellent games can shorten study time and improve students' thinking skills. Thus, the preparation of the game should pay attention to the instructional objectives. As expressed by Anna \& Bryan (2005), goals and assessments must be aligned to reflect the results of learning. Game created is expected to become one of the superior learning media.

\section{IV.Conclusions}

Based on the research has been done, it can be concluded that:

1. There are some aspects to be considered in the preparation of the game, namely artistic, navigation, and content aspect.

2. The educational game developed is feasible for use as the learning media in junior high school. It is seen from the quality of the media according to teachers and students are in the range of goodvery good.

\section{References}

Anderson, L. W., \& Krathwohl, D. R. (2001). Kerangka Landasan Untuk Pembelajaran, Pengajaran dan Asesmen Revisi Taksonomi Pendidikan Bloom. Yogyakarta: Pustaka Pelajar.

Barak, M., Ashkar, Tamar.,\&Dori, Yehudit, J. (2011). Learning Science Via Animated Movies: Its effect on students' thinking and
motivation.Computer \& Education 56, 839846

Barko, T., \& D.Sadler, T. (2012). Practically in Virtuality: Finding Student Meaning in Video Game Education. J Sci Educ Technol, 22, 124-132. doi: 10.1007/s10956-012-9381-0

Carin. (1997). Teaching Science Through Discovery. New Jersey: Prentice hall.

Chen, M.-P., \& Wang, L.-C. (2009). The Effects of Type of Interactivity in Experiential GameBased Learning. Proceedings 4th International Conference on E-Learning and Games, Edutainment

Corredor, J., Gaydos, M., \& Squire, K. (2014). Seeing Change in Time: Video Games to Teach About Temporal Change in Scientific Phenomena. J Sci Educ Technol, 23, 324343. doi: 10.1007/s10956-013-9466-4

J.R., V., Foehr, U. G., \& Roberts, D. F. (2010). GENERATION M2: Media in the Lives of 8to 18-Year-Olds Retrieved from http://www.kff.org/

Johnson, J., Shum, S. B., A.Willis, S.Bishop, T.Zamenopoulos, S.Swithenby,

D.Helbing. (2012). The FutureICT education accelarator. Eur. Phys. J. Special Topics 214, 215-243.

Khoiriah. (2016). The Effect of Multimedia-Based Teaching Materials in Science Toward Students' Cognitive Improvement. Jurnal Pendidikan IPA Indonesia, 5 (1), 75-82. doi: 10.15294/jpii.v5i1.5793

Li, M.-C., \& Tsai, C.-C. (2013). Game Based Learning in Science Education: A Review of Relevant Research. J Sci Educ Technol 22, 877-898. doi: 10.1007/s10956-013-9436-X

Mulyani, S., Liliasari, Wiji, Hana, M. N., \& E.Nursa'adah. (2016). Improving Students' Generic Skill in Science Through Chemistry Learning using ICT-Based Media On Reaction Rate and Osmotic Pressure Material. Jurnal Pendidikan IPA Indonesia, 5 (1)(April), 150-156. doi: 10.15294/jpii.v5i1.5804

Padmo, D. (2004). Teknologi Pembelajaran. Jakarta: Pusat Teknologi dan Informasi.

Sanjaya, W. (2012). Media Komunikasi Pembelajaran. Jakarta: Kencana Prenada Media Group. 
Sugiyono. (2010). Metode Penelitian Kuantitatif, Kualitatif dan $R \quad \& D$. Bandung: Penerbit Alfa Beta.

Sutrisno. (2011). Pengantar Pembelajaran Inovatif. Jakarta: Gaung Persada.

Tiawa, D. H., Mislan, N., Wibowo, S. A., \& Sumintono, B. (2012). PENGGUNAAN TEKNOLOGI INFORMASI DAN KOMUNIKASI DALAM PENGAJARAN: SURVEI PADA GURU-GURU SAINS SMP DI INDONESIA. Jurnal Pengajaran
Matematika dan Ilmu Pengetahuan Alam(Vol 17, No 1 (2012): Jurnal Pengajaran MIPA), 122-131.

Vogel et al. (2006). Computer gaming and interactive simulations for learning: a meta-analysis. $J$ Educ Comput Res 34(3):229-243.

YazdidanZandkarimi. 2013. The Impact of Elearning on some Psychological Dimensions and Academic Achievement. International Journal of Education and Learning Vol.2.No.2.pp 49-56 